\title{
Contribution of postnatally formed small beta cell aggregates to functional beta cell mass in adult rat pancreas
}

\author{
M. Chintinne • G. Stangé • B. Denys • P. In 't Veld • \\ K. Hellemans $\cdot$ M. Pipeleers-Marichal $\cdot$ Z. Ling $\cdot$ \\ D. Pipeleers
}

Received: 14 April 2010 /Accepted: 24 June 2010 /Published online: 20 July 2010

(C) Springer-Verlag 2010

\begin{abstract}
Aims/hypothesis Neogenesis of beta cells and their clustering to small aggregates is a key process in prenatal development of beta cell mass. We investigated the contribution of postnatally formed small aggregates to functional beta cell mass in adult rats.

Methods Conditions were defined for (1) counting total beta cell number in pancreases with relative error of $<10 \%$ and (2) determining their distribution over aggregates of different size and over functionally different subpopulations. Results Pancreases of 10 -week-old male Wistar rats contained $2.8 \pm 0.2 \times 10^{6}$ beta cells, of which $>90 \%$ was generated postnatally, involving: (1) neo-formation of 30,000 aggregates with diameter $<50 \mu \mathrm{m}$ including single cells; and (2) growth of 5,500 aggregates to larger sizes, accounting for $90 \%$ of the increase in cell number, with number of growing aggregates in the tail $50 \%$ greater than elsewhere. At 10 weeks, $86 \%$ of aggregates were $<50 \mu \mathrm{m}$; compared with aggregates $>200 \mu \mathrm{m}$, their beta cells exhibited a higher basal insulin content that was also resistant to glibenclamide-induced degranulation. The pool of Ki67-positive beta cells was sixfold larger than at birth and distributed over all aggregate sizes.

Conclusions/interpretation We describe a method for in situ counting of beta cell numbers and subpopulations with low relative error. In adult rats, $>90 \%$ of beta cells and beta cell aggregates are formed after birth. Aggregates $<50 \mu \mathrm{m}$ are more than 100-fold more abundant than aggregates $>200 \mu \mathrm{m}$, which are selected for isolated islet studies. Their
\end{abstract}

M. Chintinne $\cdot$ G. Stangé $\cdot$ B. Denys $\cdot$ P. In 't Veld

K. Hellemans $\cdot$ M. Pipeleers-Marichal $\cdot$ Z. Ling $\cdot$ D. Pipeleers $(\bowtie)$

Diabetes Research Center, Brussels Free University-VUB,

Laarbeeklaan 103,

1090 Brussels, Belgium

e-mail: Daniel.Pipeleers@vub.ac.be topographic and functional properties contribute to the functional heterogeneity of the beta cell population; their growth to larger aggregates with characteristic beta cell functions may serve future metabolic needs.

Keywords Endocrine pancreas · Heterogeneity · Insulin . Islet

\section{Abbreviation \\ IFI Insulin fluorescence intensity}

\section{Introduction}

The normal pancreas provides a life-long insulin supply to varying physiological needs. This requires development and maintenance of a beta cell population with a sufficient number and adequate functional capacity of the cells, collectively called functional beta cell mass [1]. Both components are also expected to determine the metabolic capacity of islet cell implants. We have previously used the number of beta cells as a quality control criterion for islet cell grafts implanted in rodents and in patients [2-4]. This helped achieve a reproducible outcome in recipients and define conditions for correction of diabetes. Longitudinal follow-up revealed a progressive loss of metabolic control [2-4], one possible cause of which could be that the functional beta cell mass in the graft was insufficient to achieve long-term control. It is so far unknown whether the implanted number of beta cells and their functional properties were comparable to those in the normal pancreas $[5,6]$. Grafts are usually prepared from isolated islets that have been separated from the exocrine tissue and its tightly bound small beta cell clusters. Single and clustered beta 
cells adjacent to ducts are seen as sites of beta cell neogenesis and subsequent beta cell proliferation in the developing pancreas [7], but their significance in adolescents and adults is unknown. They appear particularly abundant in the human pancreas [8], one reason for the low recovery of beta cells during human islet cell isolation procedures. Interestingly, implants of duct cells prepared from postnatal human organs have been shown to generate small beta cell aggregates [9, 10].

The aim of the present study was to assess the contribution of single beta cells and small beta cell aggregates (diameter $<50 \mu \mathrm{m}$ ) to functional beta cell mass in the adult rat pancreas. To this end, a method was developed for (1) counting total beta cell number in the organ with relative error under $10 \%$ and (2) determining their distribution over particles of different size, varying from single cells to islets up to $500 \mu \mathrm{m}$ in diameter. We examined to which extent postnatal neoformation and growth of particles $<50 \mu \mathrm{m}$ contributes to the adult beta cell mass and whether beta cells located in this smallest particle category differ functionally from those in large aggregates that are characteristic of islets.

\section{Methods}

Tissue processing Pancreases were obtained from seven newborn (day 2 or 3, body weight 6-8 g) and seven 10-week-old male Wistar rats (300-400 g; Janvier, Le Genest-Saint-Isle, France). Approval for animal experimentation was obtained from the local ethics committee. Studies were conducted in accordance with the Principles of Laboratory Care and supervised by a qualified veterinarian. In six of the 10-week pancreases, head and tail portions were separated through the lymph node-rich adipose tissue between omentum major and mesoduodenum. Each portion was inserted into a square-shaped holder for overnight fixation in 4\% (wt/vol.) formaldehyde. After embedding in paraffin, $5 \mu \mathrm{m}$ square sections were cut. One 10 -week pancreas was processed as 'footprint' [11-15], i.e. dissected and spread in its flat plane to make longitudinal sections from head to tail. In a second experiment, pancreases were obtained from six 10-week-old rats following treatment with glibenclamide ( $n=3$, two daily injections $2 \mathrm{mg} / \mathrm{kg}$ body weight for 2 days) or $0.9 \%$ (wt/vol.) $\mathrm{NaCl}(n=3)$ [16]; these were processed, stained and imaged in parallel so that cellular insulin staining intensities could be compared among animals.

Sections were stained for insulin to count the beta cells and to assess their degree of hormone storage [1719]. Beta cells were counted in systematically sampled sections that had been deparaffinised and stained for insulin (primary antibody: guinea pig anti-insulin, 1:1,000, overnight incubation at $4^{\circ} \mathrm{C}$; secondary antibody: Alexa Fluor 647-conjugated anti-guinea pig from Invitrogen, Paisley, UK; 1:500, $1 \mathrm{~h}$ incubation at room temperature); nuclei were stained with DAPI (Sigma-Aldrich, St Louis, MO, USA) in fluorescent mounting medium (Dako, Glostrup, Denmark). At 1:1,000 of insulin antibody, the contrast between insulinpositive cells and background was strongest, allowing highthroughput image analysis. To compare cellular fluorescence intensities, a higher dilution is needed [17, 18]; at 1:2,500 a wider intensity range was obtained without loss of weakly positive beta cells. This analysis was conducted on sections that had first been treated for antigen retrieval in citrate buffer ( $\mathrm{pH} 6.0$ at $99^{\circ} \mathrm{C}$ ), followed by overnight incubation at $4^{\circ} \mathrm{C}$ with rabbit anti-Ki67 (1:50; Acris, Herford, Germany) and anti-insulin $(1: 2,500)$, before $1 \mathrm{~h}$ incubation at room temperature with Alexa Fluor-conjugated secondary antibodies and staining in DAPI-mounting medium.

Measurement of beta cell number and beta cell distribution over aggregates For each 10-week pancreas $(n=6)$, sections of $0.72 \pm 0.16 \mathrm{~cm}^{2}$ were sampled at $250 \mu \mathrm{m}$ intervals to collect a total surface area of 25 to $31 \mathrm{~cm}^{2}$, which corresponded to $1.9 \pm 0.1 \%$ of total organ volume. For the footprint $(n=1)$, the four largest sections of head and tail were selected every $250 \mu \mathrm{m}$ over a depth of $1 \mathrm{~mm}$ leading to a total surface area of 3.7 to $4.7 \mathrm{~cm}^{2}$ or $0.33 \pm 0.01 \%$ of the volume. For neonatal pancreases $(n=7)$, one section was selected every $150 \mu \mathrm{m}$, bringing total analysed volume to $3.4 \pm 0.2 \%$ of the organ. Entire sections were stained, photographed (Pathway 855 or 435) and analysed (IPLab software; Becton Dickinson, San Jose, CA, USA) to obtain data on insulin-positive and insulin-negative surface areas, and on the number and localisation of nuclei in the insulinpositive areas (Fig. 1). By delineating individual insulinpositive cells, we ensured that insulin-positive areas did not include insulin-negative cells. Beta cell mass (milligram per pancreas) was calculated by multiplying relative insulinpositive area, as determined in sections, by pancreas weight; for each section, values were plotted (Fig. 2). Beta cell number per section was determined by automatic nuclear counting in insulin-positive areas and then extrapolated to the whole organ on the basis of the fractional volume analysed. Since the average nuclear diameter of fixed beta cells ( $7 \mu \mathrm{m}$ as determined on 25,000 nuclear profiles) exceeds the section thickness $(5 \mu \mathrm{m})$, counted beta cell numbers were corrected by a factor of 2.3 to avoid overestimation [20, 21]: this factor was determined by the formula of Abercrombie [20] for an average nuclear radius of $3.49 \mu \mathrm{m}(n=78,000)$ and a smallest detection limit of $1.11 \mu \mathrm{m}$. The automated count of insulin-positive cells was validated by a manual count in a series of sections. The average of individual beta cell volumes was calculated by dividing total beta cell volume as determined by the 


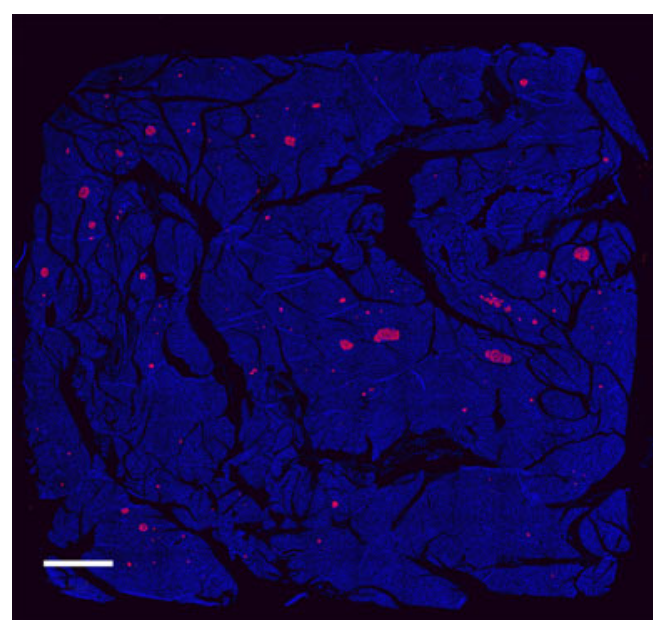

Fig. 1 Image formed by automatic montage of an entire cubical section that was immunostained for insulin (red) with nuclear DAPI staining (blue). Beta cell aggregates of variable size are irregularly distributed. Scale bar, $1 \mathrm{~mm}$

Cavalieri principle $[22,23]$ by total beta cell number. The number of beta cell aggregates was derived from counts in sections that were corrected for cut surface assuming a spherical shape.

Assessment of functional state of beta cells Beta cell populations in neonates and in 10-week-old rats were compared for their proliferating activity and for the size of their cellular hormone store. In 10-week-old rats $(n=3)$, beta cells in the smallest $(<50 \mu \mathrm{m})$ and largest $(>200 \mu \mathrm{m})$ aggregate categories were compared for the size of their hormone store and its responsiveness to glibenclamide treatment. Beta cells in proliferating activity were identified by nuclear positivity for Ki67; their number was determined for the entire organ. The size of the cellular hormone

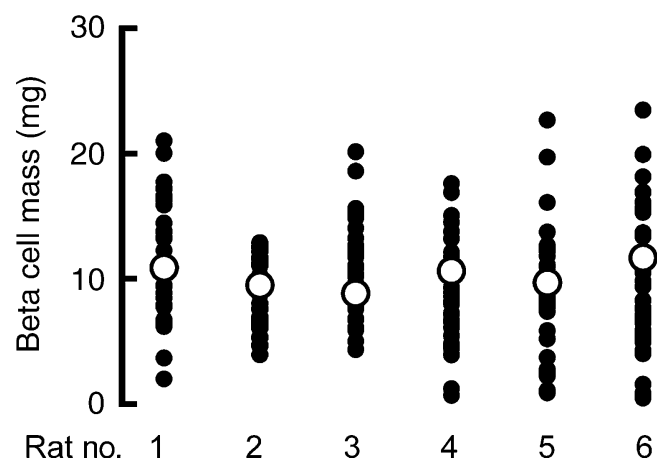

Fig. 2 Variability in values for beta cell mass as determined in individual pancreatic sections of 10-week-old rats. Each black dot represents the value from a measurement in one section that represents $0.05 \%$ of the organ volume. For each rat, 34 to 41 sections were analysed. White dot, average of all values determined for one rat. The average was thus obtained after analysis of approximately $2 \%$ of the organ volume. The averages determined in six organs were used to calculate the mean \pm SEM $(10.22 \pm 0.43 \mathrm{mg})$ store was measured through cellular fluorescence intensity following staining with an insulin antibody. Profiles of individual beta cells were selected on the basis of nuclear and cell size and then analysed for their mean insulin fluorescence intensity (IFI) using the pathway and image analysis programs in IPLab/Attovision and FlowJo (Tree Star, Ashland, OR, USA). IFI values per cell were collected for the cell's entire sectioned cytoplasm; we had previously found a close correlation between assayed cellular insulin content and recorded IFI values per cell: this control experiment was conducted on samples of FACS-purified rat beta cells (data not shown). We also calculated an average insulin content per beta cell on the basis of insulin assay measurements in pancreatic tissue extracts and the beta cell numbers counted in the same amount of tissue; these data were expressed per $\mathrm{g}$ of tissue, which normalises for differences in organ weight (Table 1).

Statistical analysis Values are expressed as means with SEM. Statistical significance was assessed with the Student's $t$ test. Relative error on beta cell mass measurements was obtained by variance components analysis of all data from six 10 -week-old pancreases in order to determine variance between pancreases and within pancreases. This allowed calculation of relative error according to sample size $(95 \% \mathrm{CI})$.

\section{Results}

Sample size needed to measure beta cell mass and number in the pancreas of 10-week-old rats To determine the sample size needed to reliably quantify beta cell mass in a pancreas, we measured the variability of values in sections of similar surface area $\left(72 \pm 16 \mathrm{~mm}^{2}\right)$. Each section was entirely scanned for its relative insulin-positive area and this percentage was multiplied by organ weight to obtain beta cell mass. In 10-week-old rats, this value markedly varied with the section (Fig. 2). With each section representing $0.05 \pm 0.01 \%$ of the pancreas and with $38 \pm 3$ sections for one pancreas, values were calculated for larger sample sizes by combining two, three or more samples successively, i.e. from $0.05 \%$ to $2.0 \%$ of the pancreas for a decrease in sample number per organ. Increasing sample size progressively reduced the variability in sample values (Fig. 3). For a relative error of $\leq 10 \%$ $(95 \% \mathrm{CI})$, a minimum of $1.2 \%$ of the total pancreas volume needs to be systematically sampled and analysed (Fig. 3); in 10-week-old pancreases, this corresponds to a total surface area of approximately $16 \mathrm{~cm}^{2}$. The variability among section values was not a consequence of the cubic embedding procedure since similar differences were found when analysing 'full footprint' sections from head and tail portions, each representing $0.33 \pm 0.01 \%$ of total organ 
Table 1 Postnatal growth in beta cell population of rat pancreas

\begin{tabular}{|c|c|c|}
\hline Age & Neonate & Week 10 \\
\hline \multicolumn{3}{|l|}{ Pancreas weight } \\
\hline Total (mg) & $24 \pm 2$ & $1242 \pm 40 * *$ \\
\hline Per g body weight & $3.2 \pm 0.2$ & $3.3 \pm 0.1$ \\
\hline \multicolumn{3}{|l|}{ Beta cell mass } \\
\hline Total (mg) & $0.77 \pm 0.07$ & $10.2 \pm 0.4 * *$ \\
\hline Per cent of pancreatic tissue & $3.2 \pm 0.2$ & $0.8 \pm 0.04 * *$ \\
\hline \multicolumn{3}{|l|}{ Number insulin-pos. aggregates $\left(\times 10^{3}\right)$} \\
\hline Total & $7.1 \pm 0.1$ & $41.7 \pm 1.8^{* *}$ \\
\hline \multicolumn{3}{|l|}{ Per size category } \\
\hline $12-50 \mu \mathrm{m}$ & $6.6 \pm 0.5$ & $35.7 \pm 1.6^{* *}$ \\
\hline $50-100 \mu \mathrm{m}$ & $0.4 \pm 0.03$ & $4.6 \pm 0.5 * *$ \\
\hline $100-200 \mu \mathrm{m}$ & $0.1 \pm 0.01$ & $1.2 \pm 0.1 * *$ \\
\hline$>200 \mu \mathrm{m}$ & $0.001 \pm 0.001$ & $0.25 \pm 0.03 * *$ \\
\hline \multicolumn{3}{|l|}{ Beta cell number } \\
\hline Total $\left(\times 10^{6}\right)$ & $0.2 \pm 0.01$ & $2.8 \pm 0.2 * *$ \\
\hline Per mg tissue $\left(\times 10^{3}\right)$ & $8.7 \pm 0.6$ & $2.3 \pm 0.1 * *$ \\
\hline Per kg body weight $\left(\times 10^{6}\right)$ & $26.8 \pm 1.6$ & $7.6 \pm 0.4 * *$ \\
\hline \multicolumn{3}{|l|}{ Per size category $\left(\times 10^{3}\right)$} \\
\hline $12-50 \mu \mathrm{m}$ & $39 \pm 2$ & $239 \pm 23 * *$ \\
\hline $50-100 \mu \mathrm{m}$ & $60 \pm 4$ & $458 \pm 32 * *$ \\
\hline $100-200 \mu \mathrm{m}$ & $96 \pm 10$ & $937 \pm 57 * *$ \\
\hline$>200 \mu \mathrm{m}$ & $6 \pm 3$ & $1202 \pm 135^{* *}$ \\
\hline \multicolumn{3}{|l|}{ Beta cell characteristics } \\
\hline \multicolumn{3}{|l|}{ Proliferation activity } \\
\hline Per cent Ki67+ cells & $5.0 \pm 1.1$ & $2.1 \pm 0.4$ \\
\hline Number Ki67+ cells $\left(\times 10^{3}\right)$ & $10 \pm 3$ & $59 \pm 7 *$ \\
\hline \multicolumn{3}{|l|}{ Hormone storage } \\
\hline Cellular insulin staining (IFI) & $1519 \pm 117$ & $1403 \pm 32$ \\
\hline \multicolumn{3}{|l|}{ Insulin content $(\mu \mathrm{g})$} \\
\hline Total & $7.7 \pm 0.5$ & $93.9 \pm 9.5^{*}$ \\
\hline Per g tissue & $327 \pm 46$ & $85 \pm 11 *$ \\
\hline Per $1 \times 10^{6}$ beta cells & $39 \pm 2$ & $38 \pm 3$ \\
\hline Cell size $\left(\mu \mathrm{m}^{2}\right)$ & $151 \pm 3$ & $187 \pm 5^{* *}$ \\
\hline
\end{tabular}

Data represent means \pm SEM in seven neonates and six 10-week-old rats for the in situ analysis, and in three neonates and three 10 -weekold rats for the measured insulin content

Statistical analysis by Student's $t$ test, ${ }^{*} p<0.05,{ }^{* *} p<0.0001$ pos., positive

volume. However, the cubic method includes the peripheral regions of the pancreas more systematically than the footprint method; since islets appear less dense in the periphery, we consider the cubic method more representative of the entire beta cell population.

For each pancreas, beta cell mass was calculated as average (Fig. 2) of 34 to 41 values, each determined in a systematically collected and entirely analysed section (Fig. 2), together $2 \%$ of the organ. The pancreas was found to contain $2.8 \pm 0.2 \times 10^{6}$ cells or $7.6 \pm 0.4 \times 10^{6}$ per kg body

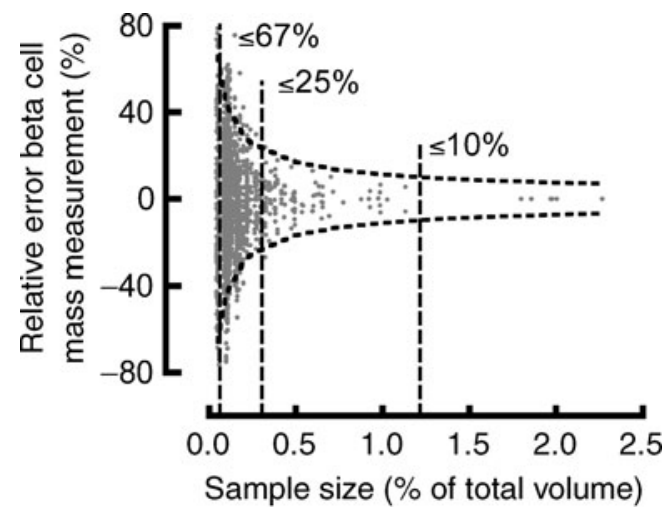

Fig. 3 Influence of sample size on the error of beta cell mass measurement in sections of the rat pancreas. Each of the six averages determined in Fig. 2 was considered to express a $0 \%$ error on the measurement of beta cell mass in one pancreas and was plotted vs the volume from which it was obtained, i.e. approximately $2 \%$ of the organ. In addition to these averages from the values in 34 to 41 sections, we calculated averages from smaller numbers of sections that were systematically selected to correspond to volumes of approximately $1 \%, 0.5 \%, 0.25 \%, 0.1 \%$ of these organs and plotted their deviation from the average of their respective organ as an error. The deviation of the values determined in individual sections was similarly included and plotted vs the corresponding volume (approximately $0.05 \%$ of organ volume). The dotted curves demarcate the $95 \%$ CI as a function of the volume analysed. Vertical dotted lines indicate minimal sample sizes for (from left to right) $\leq 67 \%, \leq 25 \%$ and $\leq 10 \%$ measurement error, at $0.05 \%, 0.26 \%$ and $1.22 \%$ respectively of the pancreatic volume

weight (Table 1). Beta cells were distributed over 41,700 particles with diameter of 12 to $500 \mu \mathrm{m}$ (Table 1); the shape of the distribution curve indicates that size does not allow a larger subpopulation to be unambiguously defined as 'islet of Langerhans' (Fig. 4). There is also no consensus definition on the minimal size of an islet $[12,24]$. We therefore named all beta cell-containing particles 'beta cell aggregates' instead of using an arbitrary cut-off to distinguish larger 'islets' from smaller 'aggregates'. Moreover, such a size concept would require inclusion of, and thus staining for, all endocrine cells, which was not the intention of the present study. The smallest category of aggregates $(<50 \mu \mathrm{m}$ including single cells; in average seven cells per particle) represented $86 \%$ of all particles and contained $8 \%$ of all beta cells; the largest $(>200 \mu \mathrm{m}$; average 4,800 cells) accounted for less than $1 \%$ of the particles, but carried $43 \%$ of the beta cells (Table 1).

Postnatal formation and growth of small beta cell aggregates We examined to which extent the size of the 10 -week beta cell population and its distribution over aggregates of varying size is the result of postnatal growth. Shortly after birth, the pancreas contained $0.20 \pm 0.01 \times 10^{6}$ beta cells, with $20 \%$ located in particles $<50 \mu \mathrm{m}$ and only $3 \%$ in those that were $>200 \mu \mathrm{m}$ (Table 1). More than $90 \%$ of the beta cells at week 10 are thus formed postnatally; this involves massive 


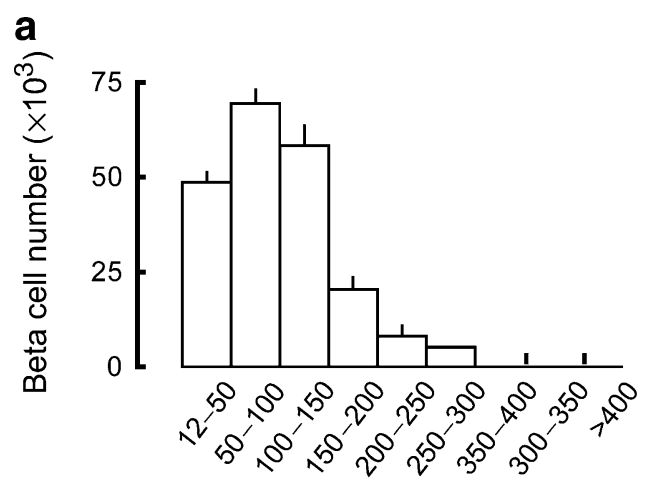

Diameter of insulin-positive aggregates $(\mu \mathrm{m})$

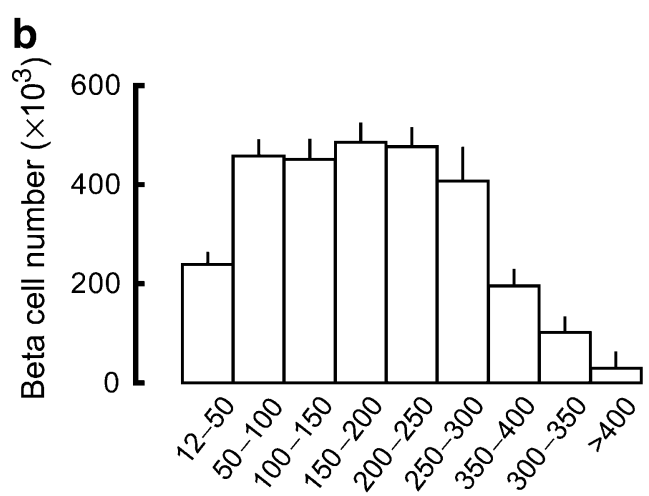

Diameter of insulin-positive aggregates $(\mu \mathrm{m})$

Fig. 4 Postnatal increase in the number of beta cells per size category of the aggregates. Distribution of beta cell number in the neonatal (a) and 10-week-old (b) pancreas over insulin-positive aggregates classified according to diameter (range 12-500 $\mu \mathrm{m}$ ). Data represent mean \pm SEM of six to seven rats. A postnatal increase in absolute number was seen for all size categories. In relative terms this increase is each time more pronounced for a larger size category

neoformation of insulin-positive particles (from 7,100 to 41,700) (Table 1) as well as growth of particles to a larger size (Table 1, Fig. 4). Over $80 \%$ of newly formed insulinpositive particles remained $<50 \mu \mathrm{m}$, but this accounted for only $8 \%$ of the increase in beta cell number; less than $1 \%$ (250 aggregates) grew to $>200 \mu \mathrm{m}$, but was responsible for $45 \%$ of the increase (Table 1). Head and tail parts exhibited a similar increase in the number of insulin-positive particles, but the tail favoured growth to a larger size. Thus twofold more larger aggregates were counted here than in the head part, and these were associated with a twofold higher beta cell number in this part (Table 2).

At week 10, the beta cell population contains sixfold higher numbers of Ki67-positive beta cells than that of neonates (Table 1), indicating that at this age markedly more beta cells are formed through proliferation than immediately after birth. This observation contradicts the view that a pool of proliferating beta cells progressively diminishes in size after birth. We did not detect any preferential localisation of Ki67-positive beta cells in small, medium or large-sized beta cell aggregates. The density of Ki67-positive beta cells was $50 \%$ higher in the tail $(54 \pm 2$ per $\mathrm{mg}$ tissue vs $34 \pm 7$ in the head, $p<0.05$ ), which can explain the growth of more smaller aggregates to the $>200 \mu \mathrm{m}$ category in this part (Table 2). The average percentage of Ki67-positive beta cells in the tail part $(2.0 \pm 0.4 \%)$ was lower than that in the neonatal pancreas $(5.0 \pm 1.1 \%)$, but this did not reach statistical significance $(p=0.0631)$.

The postnatal growth of the beta cell population did not alter its mean cellular insulin content. Beta cells in 10-week-old organs exhibited the same mean fluorescence intensities per cell as those in neonates, although they presented a $20 \%$ larger surface area (Table 1). There was also no difference in mean insulin content of neonatal and adult beta cells, when these were calculated from the hormone assay data in pancreatic extracts and cell counts in equivalent amounts of tissue (Table 1). When beta cells were FACS-purified at both ages, no differences were measured in their respective insulin content $\left(44.4 \pm 3.3 \mathrm{ng}\right.$ per $1 \times 10^{3}$ beta cells at 10 weeks and $41.3 \pm 2.2 \mathrm{ng}$ per $1 \times 10^{3}$ beta cells at birth), indicating that both stages contained well-granulated beta cells.

Insulin storage function in small beta cell aggregates The intercellular differences in insulin content represent one feature of the functional heterogeneity in the beta cell population $[5,6]$. We examined whether they are related to the size of the beta cell aggregates. Mean cellular fluorescence intensity of beta cells in small aggregates $(<50 \mu \mathrm{m})$ was $40 \%$ higher than that in $>200 \mu \mathrm{m}$ aggregates $(p<0.002)$. Individual values in small aggregates exhibited a wider range tending towards a high content (P10-P90 range $511-2,859$ vs $547-1,765$ in $>200 \mu \mathrm{m}$ aggregates). This was related to the presence of markedly more beta cells with high insulin content, as illustrated by the percentages of beta cells with low, medium or high insulin content in small and large aggregates. These three subpopulations were defined by the P10 (low) and P90 (high) values in $>200 \mu \mathrm{m}$ aggregates (Table 3). Thus, large aggregates contained $10 \%$ low, $80 \%$ medium and $10 \%$ high insulin content cells. In small aggregates $40 \%$ of beta cells exceeded the P90 value of the large aggregates; moreover, their mean insulin content was $25 \%$ higher than that in the P90 category of large aggregates (Table 3). Small and large aggregates contained similar percentages of low insulin content cells.

Prior glibenclamide treatment exerted its degranulating effect predominantly in beta cells of large aggregates, which after treatment contained virtually no high content beta cells, whereas their percentage of low content beta cells had doubled and their medium subpopulation exhibited a $20 \%$ reduction in insulin content (Table 3 ). On the other hand, few changes occurred in small aggregates: 
Table 2 Beta cell distribution in head and tail portions of pancreas in 10 -week-old rats

\begin{tabular}{lcc}
\hline Portion & Head & Tail \\
\hline Tissue weight $(\mathrm{mg})$ & $619 \pm 40$ & $623 \pm 43$ \\
Beta cell mass & & \\
Total $(\mathrm{mg})$ & $4.07 \pm 0.38$ & $1.0 \pm 0.1^{* *}$ \\
Per cent of pancreatic tissue & $0.7 \pm 0.05$ & \\
Number of insulin-positive aggregates $\left(\times 10^{3}\right)$ & & $33.7 \pm 2.6$ \\
Per g tissue & $34.4 \pm 2.2$ & \\
Per size category per g tissue & & $27.9 \pm 2.0^{*}$ \\
$12-50 \mu \mathrm{m}$ & $30.5 \pm 2.5$ & $4.4 \pm 0.5^{*}$ \\
$50-100 \mu \mathrm{m}$ & $3.0 \pm 0.4$ & $1.0 \pm 0.1^{*}$ \\
$100-200 \mu \mathrm{m}$ & $0.7 \pm 0.1$ & $0.28 \pm 0.03^{*}$ \\
$>200 \mu \mathrm{m}$ & $0.14 \pm 0.02$ & $1.7 \pm 0.1^{*}$ \\
Beta cell number & & $2.7 \pm 0.2^{* *}$ \\
Total $\left(\times 10^{6}\right)$ & $1.2 \pm 0.1$ & \\
Per mg tissue $\left(\times 10^{3}\right)$ & $1.9 \pm 0.1$ & $0.2 \pm 0.01$ \\
Per size category $\left(\times 10^{3} / \mathrm{mg}\right.$ tissue $)$ & & $0.4 \pm 0.03$ \\
$12-50 \mu \mathrm{m}$ & $0.2 \pm 0.03$ & $0.8 \pm 0.1$ \\
$50-100 \mu \mathrm{m}$ & $0.3 \pm 0.03$ & $1.3 \pm 0.2^{* *}$ \\
$100-200 \mu \mathrm{m}$ & $0.7 \pm 0.04$ & \\
$>200 \mu \mathrm{m}$ & $0.6 \pm 0.1$ &
\end{tabular}

no increase in percentage of beta cells with low content, no decrease in mean insulin content of the medium subpopulation and only a modest decrease in percentage of high content cells without reduction in their mean insulin content (Table 3). These data demonstrate that beta cells of small aggregates are markedly less sensitive to the degranulating effect of glibenclamide; the lack of such effect is not caused by a low degree of granulation.

\section{Discussion}

Restoring functional beta cell mass is a major goal in diabetes therapy. Strategies are being developed for replac- ing depleted beta cell mass by regeneration in the pancreas or by beta cell implant at an ectopic site. Such strategies need to be guided by data on the beta cell population in the normal pancreas and in animal models of cell therapy. Thus methods are required that can reliably quantify beta cell numbers in situ and assess their functional state. The method and data described in the present study can contribute to this requirement.

To estimate the size of the beta cell population in the intact pancreas, beta cell mass is most often determined on the basis of pancreas weight [12, 15, 25-28] or volume [11, 14, 29, 30], and relative insulin-positive area as measured in tissue sections. Values vary with the number of beta cells, but also with differences in beta cell size or changes

Table 3 Comparison of insulin content in beta cells in small $(<50 \mu \mathrm{m})$ vs those in large $(>200 \mu \mathrm{m})$ aggregates

\begin{tabular}{|c|c|c|c|c|}
\hline \multirow[t]{2}{*}{ Insulin content } & & \multicolumn{3}{|c|}{ Percentage of beta cells (average cellular IFI) } \\
\hline & & Low & Medium & High \\
\hline \multirow[t]{2}{*}{ Aggregates $>200 \mu \mathrm{m}$} & Control & $8 \pm 2(457 \pm 7)$ & $82 \pm 2(1137 \pm 37)$ & $10 \pm 1(2,065 \pm 18)$ \\
\hline & Glibenclamide & $18 \pm 5(452 \pm 4)$ & $81 \pm 4(911 \pm 52)^{\dagger}$ & $1 \pm 1^{\dagger \dagger}(2,105 \pm 12)$ \\
\hline \multirow[t]{2}{*}{ Aggregates $<50 \mu \mathrm{m}$} & Control & $11 \pm 2(438 \pm 5)$ & $49 \pm 4 * *(1,150 \pm 28)$ & $40 \pm 2 * *(2,581 \pm 81)^{* *}$ \\
\hline & Glibenclamide & $15 \pm 1(440 \pm 3)$ & $55 \pm 1 * *(1,088 \pm 6)^{*}$ & $31 \pm 0.4^{\dagger} * * * *(2,473 \pm 25) * *$ \\
\hline
\end{tabular}

Data represent means \pm SEM of three independent paired experiments and express the percentage of beta cells that exhibit the $<\mathrm{P} 10$ (low), P10 P90 (medium) and >P90 (high) values of cellular IFI measured in beta cells of aggregates $>200 \mu \mathrm{m}$ in control animals. By definition, large aggregates in controls contain $10 \%$ cells in the low, $80 \%$ in the medium and $10 \%$ in the high category. The average cellular IFI in each group is shown in parentheses

Statistics Student's $t$ test: ${ }^{*} p<0.05,{ }^{* *} p<0.005,{ }^{* *} p<0.0001$ for aggregates $<50$ vs $>200 \mu \mathrm{m} ;{ }^{\dagger} p<0.05,{ }^{\dagger \dagger} p<0.005$ for glibenclamide vs controls 
in the density of beta cells and of non-endocrine tissue. The number of beta cells can be calculated by dividing total beta cell volume by the mean volume of individual beta cells also measured in sections [11, 15, 25, 30, 31]; these values overestimate actual numbers, since individual cell volumes are determined in tissue shrunken during paraffin embedding. The disector method allows a direct and more accurate count of beta cell numbers [21,23] but is difficult to apply on the sufficiently large tissue samples needed to reduce relative error. Several reasons thus account for the wide range, and sometimes discrepancies in values reported for size of the beta cell population [21, 23, 25, 31]: (1) differences in methods and read-outs; (2) influences by other factors than beta cell number; and (3) variability among strains and between species. Variability in tissue and sampling conditions, or lack of this information, makes interpretations and extrapolation to the whole organ difficult. Several studies have adequately followed criteria to control relative errors of point counting with respect to the entire section [32-37], but few provided information on how representative the examined section(s) were for the entire organ.

With the method described by us, the number of beta cells is directly and automatically counted in entire sections. We show that $1.2 \%$ of the adult rat pancreas needs to be systematically sampled to yield data with error rates $<10 \%$. Sample size is not always mentioned in the literature, and if so, does not often reach this level. Pancreases of young adult male Wistar rats (aged 10 weeks) were found to contain $2.8 \pm 0.2 \times 10^{6}$ beta cells, which corresponds to $7.6 \pm 0.4 \times 10^{6}$ per $\mathrm{kg}$ body weight; this number may further increase with age and may also vary with the strain, as was the case in mice [28]. It is also in the range of beta cell numbers that corrected diabetes following intraportal transplantation in R/A Wistar or Lewis rats of similar age $[2,38]$. The number above is distributed over 42,000 beta cell clusters with diameter varying from that of single cells to that of large islets $(12-500 \mu \mathrm{m})$. Beta cell clusters were divided into four size classes. The smallest $(<50 \mu \mathrm{m}$, one to ten sectioned beta cells) were the most abundant $(86 \%)$, but contributed only $8 \%$ to total beta cell number. The largest $(>200 \mu \mathrm{m})$ was rare $(<1 \%$ of all particles), but contained $43 \%$ of all beta cells. Previous analyses of aggregate sizes were often limited to particles $>50 \mu \mathrm{m}$. They also found the smallest islets to be the most numerous with a relatively small contribution to total islet volume; this led to the proposal that analysis of the pancreatic beta cell population could be restricted to the larger islets as they represent the majority of the cells [24, 39]. There are, however, several arguments against excluding small beta cell aggregates from analysis. First, no particle size has so far been defined to exclude beta cells from studies. Second, the number of beta cells in the smallest category can vary with (patho)physiological conditions, with aggregates $<50 \mu \mathrm{m}$ carrying $20 \%$ of all beta cells in neonates. Third, a number that seems quantitatively negligible is not necessarily qualitatively so.

In vitro and in vivo evidence exists for a functional heterogeneity in the beta cell population [6]. It is conceivable that some intercellular differences in function are related to the size of the beta cell aggregate. Small aggregates are often juxtaposed to duct cells and may thus contain newly formed beta cells [8]. The microenvironment of their beta cells may differ from that in large aggregates [40] and thus cause differences in their functional state. We noticed that small aggregates $(<50 \mu \mathrm{m})$ contained beta cells with higher basal insulin content than large aggregates of the size that is usually selected for in vitro studies $(>200 \mu \mathrm{m})$. Contrary to the latter, they exhibited little signs of degranulation following 2 days glibenclamide treatment. This may reflect an insensitivity to the drug in cells that are not yet fully differentiated or are subject to environmental conditions interfering with the drug's effect. Prior work also noticed a stronger insulin immune reactivity in small islets [18] and a heterogeneity in glibenclamide-induced degranulation [19]. The physiological relevance of small beta cell aggregates with a functionally different state is still unclear. Clarification will require further studies of the intact pancreas, since dispersion causes a variable disruption of aggregates and will by itself influence the functional state of the cells. Furthermore, it is at present not technically possible to separate beta cell aggregates according to the listed size categories and enrich them so that they can be functionally analysed under comparable conditions. The methods described in the present study should help further in situ analysis.

Our observations also indicate that in vitro studies on islet cell preparations cannot be seen as representative of the total pancreatic beta cell population. They are undertaken on samples from the large beta cell aggregates. In our laboratory, we obtain 300 to 400 islets from 10-week-old male Wistar rats following collagenase digestion, separation of the largest particles and hand-picking [38]. After dissociation and FACS-purification [38], this approach yields an average of $3 \times 10^{5}$ beta cells per pancreas, corresponding in number to approximately $10 \%$ of the total beta cell population in the organ, but in function to the largest aggregates.

More than $90 \%$ of the beta cells in 10 -week-old rats are generated postnatally. This involves formation of approximately 30,000 new aggregates $<50 \mu \mathrm{m}$ and growth of 5,500 towards a diameter $>50 \mu \mathrm{m}$. Only 250 aggregates grow to a diameter $>200 \mu \mathrm{m}$, but this accounts for almost $50 \%$ of the postnatal increase in beta cell number. A postnatal shift towards larger aggregates was also described in previous work [24, 39], but not quantified by following the number 
and sizes of existing and novel beta cell aggregates. In neonates, virtually all beta cell aggregates were $<50 \mu \mathrm{m}$; their number is in the range of the number of aggregates $>50 \mu \mathrm{m}$ at 10 weeks. It is thus conceivable that the small neonatal aggregates represent nuclei for postnatal growth by beta cell proliferation and/or by neogenesis. In addition to the growth of small aggregates, there is a massive postnatal formation of small insulin-positive aggregates, which may originate from differentiating beta cell progenitors [41] or from transdifferentiating exocrine cells [42]. According to a tracing lineage study in mice, $17 \%$ of insulin-positive cells in 4-week-old animals were postnatally derived from exocrine duct cells [43]; it would be interesting to examine whether these cells appear in aggregates $<50 \mu \mathrm{m}$. Newly formed small beta cell aggregates may fuse and/or grow into larger aggregates depending on the metabolic needs and/or environmental conditions.

Growth to larger aggregates was more pronounced in the tail part than in the head of the pancreas, which resulted in a higher content of beta cells in that section. This might thus be caused by the presence of more beta cell aggregates in the neonatal pancreas tail or of a microenvironment that favours postnatal growth of small particles in this part. Proliferation of beta cells was detected in all size categories indicating its involvement in the growth of beta cell aggregates. In fact, the pool of beta cells in proliferative activity increased sixfold during this period, contradicting views that the proliferating pool of beta cells decreases after birth.

Acknowledgements The authors thank L. Kaufman and D. Coomans for statistical advice, and S. Uyttenhove and N. van Slycke for excellent administrative support. They are grateful to N. Buelens and K. van Belle for technical assistance in preparing tissue sections for analysis. This work was supported by grants from Research Foundation Flanders (FWO-G.0400.07), from the Belgian Inter-University Poles of Attraction Program (IUAP P6/40), from the 6th EU-framework (BetaCellTherapy number 512145) and from Flanders Institute Science and Technology (SBO-040084). M. Chintinne and B. Denys are PhD fellows of FWO.

Duality of interest The authors declare that there is no duality of interest associated with this manuscript.

\section{References}

1. Pipeleers D, Chintinne M, Denys B, Martens G, Keymeulen B, Gorus F (2008) Restoring a functional beta-cell mass in diabetes. Diabetes Obes Metab 10(Suppl 4):54-62

2. Keymeulen B, Korbutt G, de Paepe M, Gorus F, Kloppel G, Pipeleers DG (1996) Long-term metabolic control by rat islet grafts depends on the composition of the implant. Diabetes 45:1814-1821

3. Keymeulen B, Ling Z, Gorus FK et al (1998) Implantation of standardized beta-cell grafts in a liver segment of IDDM patients: graft and recipients characteristics in two cases of insulin- independence under maintenance immunosuppression for prior kidney graft. Diabetologia 41:452-459

4. Keymeulen B, Gillard P, Mathieu C et al (2006) Correlation between beta cell mass and glycemic control in type 1 diabetic recipients of islet cell graft. Proc Natl Acad Sci USA 103:17444-17449

5. Pipeleers DG (1992) Heterogeneity in pancreatic beta-cell population. Diabetes 41:777-781

6. Pipeleers D, Kiekens R, Ling Z, Wilikens A, Schuit F (1994) Physiologic relevance of heterogeneity in the pancreatic beta-cell population. Diabetologia 37(Suppl 2):S57-S64

7. Bouwens L, Wang RN, de Blay E, Pipeleers DG, Kloppel G (1994) Cytokeratins as markers of ductal cell differentiation and islet neogenesis in the neonatal rat pancreas. Diabetes 43:1279-1283

8. Bouwens L, Pipeleers DG (1998) Extra-insular beta cells associated with ductules are frequent in adult human pancreas. Diabetologia 41:629-633

9. Bogdani M, Lefebvre V, Buelens N et al (2003) Formation of insulin-positive cells in implants of human pancreatic duct cell preparations from young donors. Diabetologia 46:830-838

10. Suarez-Pinzon WL, Lakey JR, Brand SJ, Rabinovitch A (2005) Combination therapy with epidermal growth factor and gastrin induces neogenesis of human islet beta-cells from pancreatic duct cells and an increase in functional beta-cell mass. J Clin Endocrinol Metab 90:3401-3409

11. Bonner-Weir S (2001) beta-cell turnover: its assessment and implications. Diabetes 50(Suppl 1):S20-S24

12. Butler AE, Janson J, Soeller WC, Butler PC (2003) Increased beta-cell apoptosis prevents adaptive increase in beta-cell mass in mouse model of type 2 diabetes: evidence for role of islet amyloid formation rather than direct action of amyloid. Diabetes 52:2304-2314

13. Zhong L, Georgia S, Tschen SI, Nakayama K, Bhushan A (2007) Essential role of Skp2-mediated p27 degradation in growth and adaptive expansion of pancreatic beta cells. J Clin Invest 117:2869-2876

14. Wang RN, Bouwens L, Kloppel G (1994) Beta-cell proliferation in normal and streptozotocin-treated newborn rats: site, dynamics and capacity. Diabetologia 37:1088-1096

15. Manesso E, Toffolo GM, Saisho Y et al (2009) Dynamics of betacell turnover; evidence for beta-cell turnover and regeneration from sources of beta-cells other than beta-cell replication in the HIP rat. Am J Physiol Endocrinol Metab 297:E323-E330

16. Ling Z, Wang Q, Stange G, In't Veld P, Pipeleers D (2006) Glibenclamide treatment recruits beta-cell subpopulation into elevated and sustained basal insulin synthetic activity. Diabetes 55:78-85

17. Rahier J, Stevens M, de Menten Y, Henquin JC (1989) Determination of antigen concentration in tissue sections by immunodensitometry. Lab Invest 61:357-363

18. Jorns A (1994) Immunocytochemical and ultrastructural heterogeneities of normal and glibenclamide stimulated pancreatic beta cells in the rat. Virchows Arch 425:305-313

19. Stefan Y, Meda P, Neufeld M, Orci L (1987) Stimulation of insulin secretion reveals heterogeneity of pancreatic B cells in vivo. J Clin Invest 80:175-183

20. Abercrombie M (1946) Estimation of nuclear population from microtome sections. Anat Rec 94:239-247

21. Bock T, Svenstrup K, Pakkenberg B, Buschard K (1999) Unbiased estimation of total beta-cell number and mean betacell volume in rodent pancreas. APMIS 107:791-799

22. Gundersen HJ, Jensen EB, Kieu K, Nielsen J (1999) The efficiency of systematic sampling in stereology-reconsidered. J Microsc 193:199-211 
23. Svenstrup K, Skau M, Pakkenberg B, Buschard K, Bock T (2002) Postnatal development of beta-cells in rats. Proposed explanatory model. APMIS 110:372-378

24. Hellman B (1959) The numerical distribution of the islets of Langerhans at different ages of the rat. Acta Endocrinol (Copenh) 32:63-77

25. Montanya E, Nacher V, Biarnes M, Soler J (2000) Linear correlation between beta-cell mass and body weight throughout the lifespan in Lewis rats - role of beta-cell hyperplasia and hypertrophy. Diabetes 49:1341-1346

26. Rahier J, Goebbels RM, Henquin JC (1983) Cellular composition of the human diabetic pancreas. Diabetologia 24:366-371

27. Stefan Y, Orci L, Malaisselagae F, Perrelet A, Patel Y, Unger RH (1982) Quantitation of endocrine cell content in the pancreas of non-diabetic and diabetic humans. Diabetes 31:694-700

28. Bock T, Pakkenberg B, Buschard K (2005) Genetic background determines the size and structure of the endocrine pancreas. Diabetes 54:133-137

29. Butler AE, Janson J, Bonner-Weir S, Ritzel R, Rizza RA, Butler PC (2003) Beta-cell deficit and increased beta-cell apoptosis in humans with type 2 diabetes. Diabetes 52:102-110

30. Meier JJ, Butler AE, Saisho Y et al (2008) Beta-cell replication is the primary mechanism subserving the postnatal expansion of beta-cell mass in humans. Diabetes 57:1584-1594

31. Wang RN, Bouwens L, Kloppel G (1996) Beta-cell growth in adolescent and adult rats treated with streptozotocin during the neonatal period. Diabetologia 39:548-557

32. Weibel ER (1979) Point counting methods. In: Weibel ER (ed) Stereological methods. Academic, London, pp 101-161

33. Bonner-Weir S, Deery D, Leahy JL, Weir GC (1989) Compensatory growth of pancreatic beta-cells in adult rats after short-term glucose infusion. Diabetes 38:49-53
34. Montana E, Bonner-Weir S, Weir GC (1993) Beta cell mass and growth after syngeneic islet cell transplantation in normal and streptozocin diabetic C57BL/6 mice. J Clin Invest 91:780-787

35. Rahier J, Guiot Y, Goebbels RM, Sempoux C, Henquin JC (2008) Pancreatic beta-cell mass in European subjects with type 2 diabetes. Diabetes Obes Metab 10(Suppl 4):32-42

36. Rahier J, Wallon J, Henquin JC (1981) Cell populations in the endocrine pancreas of human neonates and infants. Diabetologia 20:540-546

37. Scaglia L, Cahill CJ, Finegood DT, Bonner-Weir S (1997) Apoptosis participates in the remodeling of the endocrine pancreas in the neonatal rat. Endocrinology 138:1736-1741

38. Pipeleers DG, Pipeleers-Marichal M, Hannaert JC et al (1991) Transplantation of purified islet cells in diabetic rats. I. Standardization of islet cell grafts. Diabetes 40:908-919

39. Hellman B (1959) The volumetric distribution of the pancreatic islet tissue in young and old rats. Acta Endocrinol (Copenh) 31:91-106

40. Malaisse-Lagae F, Ravazzola M, Robberecht P, Vandermeers A, Malaisse WJ, Orci L (1975) Exocrine pancreas: evidence for topographic partition of secretory function. Science 190:795-797

41. Xu X, D'Hoker J, Stange G et al (2008) Beta cells can be generated from endogenous progenitors in injured adult mouse pancreas. Cell 132:197-207

42. Baeyens L, de Breuck S, Lardon J, Mfopou JK, Rooman I, Bouwens L (2005) In vitro generation of insulin-producing beta cells from adult exocrine pancreatic cells. Diabetologia 48:49-57

43. Inada A, Nienaber C, Katsuta $\mathrm{H}$ et al (2008) Carbonic anhydrase II-positive pancreatic cells are progenitors for both endocrine and exocrine pancreas after birth. Proc Natl Acad Sci USA 105:19915-19919 